\title{
THE IMPACT OF TRANSPORT TIME ON THE CARRIER'S COSTS
}

DOI 10.2478/ntpe-2018-0027

\author{
doc. Ing. Miloš Poliak, PhD. \\ Ing. Juraj Hammer \\ University of Zilina, Slovak Republic \\ dr hab. inż. Marek Jaśkiewicz, prof. PSk \\ Kielce University of Technology, Poland \\ dr inż. K. Zielonka \\ Automotive Industry Institute (PIMOT), Poland \\ dr inż. J. Stokłosa \\ University of Economics \\ and Innovation in Lublin, Poland
}

\begin{abstract}
In freight road transport, the price per unit of transport is not the same for each shipment for reason, that many factors influence the cost of shipping. An important aspect, in addition to cost inputs, which decides, how high will the shipping cost it is the destination where the transportation takes place. The purpose of this article is to identify the impact of the change of destination on carrier costs. Authors will not deal with specific costs related to the change of destination, which include, for example, charges for the use of the road network or travel compensation to the driver, but will only deal with the probability of vehicle back-up. If the carrier is unable to backhaul of the vehicle, the initial shipping costs increase significantly.
\end{abstract}

Keywords: freight transport, transport time, backhaul, costs

\section{INTRODUCTION}

There is a large competitive environment in the road freight market, where many transport companies operate. Every transport company wants to keep on the transport market with a view to achieving profit and prosperity. Based on the definition of a strategy by carriers to achieve the prosperity, is often the decisive price for shipping. At present there is a welldeveloped issue of cost calculation. Even small carriers are able to calculate the highest cost items, which include the cost of fuel, driver wages and toll costs (Poliak, 2013). There is, however, an opinion between carriers, that the calculated cost per unit of performance is unchanged (Ondruš and Dicová, 2010). The price of road freight transport in Europe ranges from $0.85-1.2 € / \mathrm{km}$. The cost of shipping is not cost-dependent, but also from the possibility of backhaul traffic the vehicle (Blendon et al., 1997). If the vehicle is not used by backhaul and the vehicle performs a reverse journey without a shipment, carrier costs are doubled when compared to the situation, if the vehicle would also carry backhaul. The purpose of this paper is to identify the impact of the shipment destination at the carrier's expense related to transport (Cyprich et al., 2013).

\section{GENERAL PRINCIPLES FOR PRICING IN FREIGHT ROAD TRANSPORT}

When creating a prize, it is essential to rely on the carrier's costs, and it is necessary to address the appropriateness of the rate in $€ / \mathrm{km}$, which is commonly used on the market. If the carrier enters into a long-term contract for multiple shipments for one customer and will know what driving performance will be realized for the foreseeable period, it is also possible to use the rate in $€ / \mathrm{km}$. This rate is also preferred over long distances, for which the carrier makes use of the available time of the driver's work to drive the vehicle (Drozdziel and Piasecki, 1995). It is also necessary to take into account the facts about transport price andttt get input data for (Grand and Duret, 2000): 
- the vehicle's day in service for the previous period,

- driving performance over the previous period,

- the most detailed and most detailed breakdown of the carrier's cost over the previous period,

- driving performance (distance traveled, including unladen driving) for which the preliminary cost calculation $(L x)$.

- carrier costs are variable and fixed,

- fixed costs are calculated for one day in service per relationship:

$$
\mathrm{N}_{\mathrm{FD}}=\frac{\mathrm{N}_{\mathrm{F}}}{\mathrm{VD}_{\mathrm{pr}}}(€ / \text { day })
$$

where:

$\mathrm{N}_{F D}$ - fixed daily costs,

$\mathrm{N}_{\mathrm{F}}$ - fixed costs,

$\mathrm{VD}_{\mathrm{pr}}$ - vehicle days in service

- unit variable costs are calculated:

$$
\mathrm{n}_{\mathrm{v}}=\frac{\mathrm{N}_{\mathrm{V}}}{\mathrm{L}}(€ / \mathrm{km})
$$

where:

$\mathrm{n}_{v}$ - costs variable,

$\mathrm{N}_{v}$ - costs variable,

$\mathrm{L}$ - driving performance

Based on these input data, the shipping cost can be calculated consisting of the proportion of time costs and the proportion of variable costs (Poliak et al., 2015). The costs need to be increased of required proportion (Rotondo, 2013). The resulting price is also influenced by the option by carrier backhaul the vehicle. If the carrier has an option directly from the place of unloading backhaul of vehicle, price or costs need not be increased (Lubanski, 2000). However, there are cases when the carrier is unable to backhaul the vehicle. If we consider the extreme situation, that the carrier does not backhaul the vehicle, carrier costs rise to twice and these costs must be charged to the shipper, who requested to ship the shipment to a destination without reloading the vehicle(Gnap et al., 2003). This means both variable and time costs in double the amount (Osterloh and Debus, 2012). Based on this assumption, we will continue to identify individual destinations but also a specific destination in terms of time during the week, because there is a presumption that the bids offer will change over the course of the week (Edwards and Keen, 1996).

\section{RESEARCH RESPOSIBLE FOR BACKHAUL OF VEHICLES}

The possibilities of the vehicles backhaul was carried out for the back-up of the vehicle into the scope of the carrier that is in Slovakia. Research could be applied to any state. The authors have analyzed shipping bids to identify the back-up potential in traffic data for a period of 3 months (from february to april 2018). The research was conducted not only for business days, but also over the weekend. The authors focuse on 19 observed countries of backhaul, including the Slovene Republic, which is the implementation of national transport in the SR. The countries in the observed sample were deliberately chosen. The primary reason was diversity, differentiation between selected countries. Representations within Europe are Southern European, Western European and Eastern European countries so that all regions of the EU are covered by research. The statistical data set is drawn up the matrix of supply of transport links within states in the range of monday to sunday. Table 1 shows the shipping offer matrix to the Slovak Republic from 19 European countries. The value in Table 1 represents, what proportion of vehicles, who are looking for transportation from a specific state are able to get the transport of that day. For example, from Belgium on monday of the total supply of transport capacity, only $11.5 \%$ of the vehicles will be occupied by transport. Other vehicles must carry a shipment without a shipment, or wait for the next day or to transfer the empty vehicle to another state. The highest offer of backhaul vehicles, excluding domestic 
transport, is from the Czech Republic, Poland and Austria. On the contrary, the lowest option of vehicles bachaul is from the Balkans, Serbia $-2.3 \%$, Romania $-4.9 \%$. This means that after calculating the price free of charge for the use of roads it is then necessary to increase the risk, that the vehicle will not be back-up. Since the risk is higher than countries such as Serbia, Romania, Bulgaria and so on, the price per unit of performance is higher for these countries.

Table 1.

The matrix of travel services to the Slovak Republic.

\begin{tabular}{|l|r|r|r|r|r|r|r|c|}
\hline \multicolumn{1}{|c|}{ States } & Mon & Tue & Wed & Thur & Fri & Sat & Sun & Average \% \\
\hline Belgium & 11.5 & 11.0 & 12.0 & 13.0 & 15.8 & 12.0 & 10.8 & 12.3 \\
\hline Bulgaria & 6.5 & 8.0 & 7.8 & 7.8 & 9.0 & 7.5 & 7.3 & 7.7 \\
\hline Czech Republic & 77.3 & 78.7 & 82.5 & 81.3 & 82.2 & 77.3 & 75.5 & 79.2 \\
\hline France & 11.0 & 8.7 & 9.8 & 11.8 & 11.6 & 11.8 & 10.5 & 10.7 \\
\hline Netherland & 20.8 & 20.0 & 18.3 & 24.3 & 27.0 & 23.0 & 21.0 & 22.0 \\
\hline Luxemburg & 8.8 & 10.0 & 17.8 & 6.3 & 10.4 & 5.5 & 5.8 & 9.2 \\
\hline Hungary & 24.3 & 26.0 & 23.5 & 27.3 & 31.6 & 29.0 & 26.3 & 26.8 \\
\hline Germany & 19.3 & 18.3 & 16.3 & 17.5 & 20.2 & 19.8 & 20.0 & 18.8 \\
\hline Poland & 48.5 & 49.3 & 51.3 & 53.5 & 56.4 & 50.3 & 47.8 & 51.0 \\
\hline Austria & 43.3 & 47.3 & 43.0 & 42.0 & 45.0 & 45.5 & 46.0 & 44.6 \\
\hline Romania & 4.0 & 4.0 & 4.8 & 5.0 & 6.2 & 5.3 & 4.8 & 4.9 \\
\hline Slovakia & 70.0 & 69.7 & 73.0 & 72.5 & 72.2 & 70.3 & 67.3 & 70.7 \\
\hline Slovenia & 45.0 & 40.3 & 46.8 & 51.8 & 53.0 & 49.0 & 49.5 & 47.9 \\
\hline Serbia & 2.3 & 2.7 & 2.5 & 2.0 & 2.6 & 2.0 & 2.0 & 2.3 \\
\hline Spain & 9.0 & 9.0 & 9.0 & 9.5 & 12.0 & 9.0 & 8.8 & 9.5 \\
\hline Switzerland & 2.5 & 4.7 & 3.8 & 3.0 & 5.6 & 2.8 & 3.0 & 3.6 \\
\hline Italy & 34.0 & 33.7 & 33.8 & 37.5 & 43.6 & 39.0 & 37.3 & 37.0 \\
\hline Turkey & 7.3 & 6.7 & 9.5 & 7.0 & 5.8 & 5.8 & 6.3 & 6.9 \\
\hline Great Britian & 14.8 & 16.3 & 13.8 & 17.0 & 20.2 & 20.3 & 17.3 & 17.1 \\
\hline Average (\%) & 24.2 & 24.4 & 25.2 & 25.8 & 27.9 & 25.5 & 24.6 & 25.4 \\
\hline
\end{tabular}

Source: processed by the authors

Probability of acquisition backhaul transportation in a particular state is changing even within one week. For example in the UK, the proportion of laden vehicles is on monday at $14.8 \%$, on friday rises to $20.2 \%$. Our goal is to identify, whether the development is individual for each country, or are common features of development within all countries possibilities of backhaul vehicles. Summarized assessment of all countries (Fig. 1), it can be stated that significantly more vehicles are able to get back shipping to Slovakia at the end of the week (thursday, friday and saturday) compared to the rest of the week.

\section{Back Hual In Days to SR}

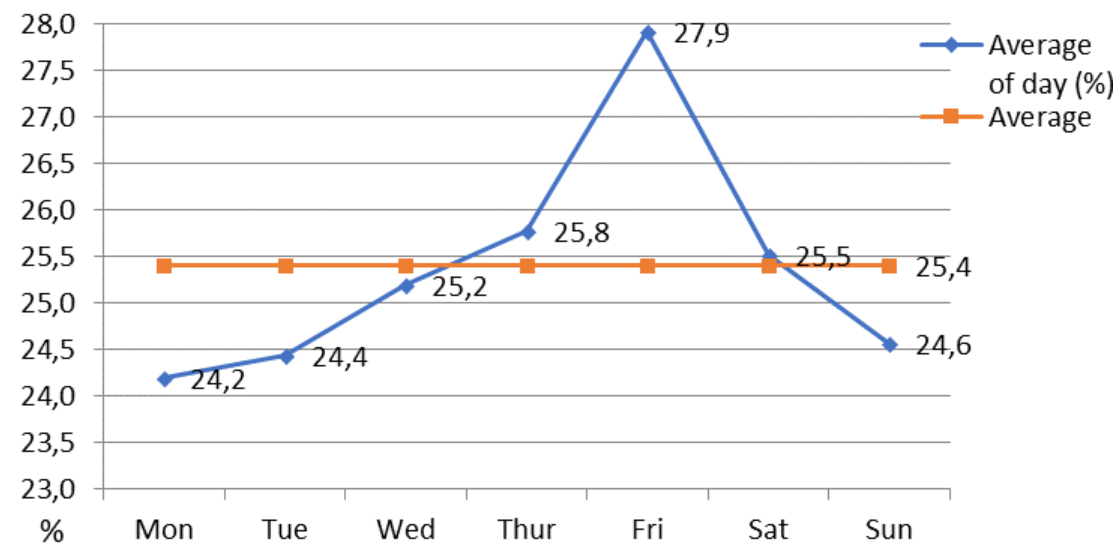

Fig. 1. Average shipping offer values of backhaul vehicles to SR.

Source: processed by the authors

That is, when negotiating the price account should also be taken of the fact, if it is planned to unload (Lai, 2010). If landing is on thursday or friday, there is a higher possibility to get the 
transport, which reduces transport costs. On the other hand, additional costs need to be taken into account, which arise with loading and starting transport on fridays. These include, for example, sunday driving ban, which increases the cost of travel compensation for the driver.

\section{DIVISION OF GOODS DELIVERY COUNTRY BY VEHICLES TO SLOVAKIA}

The previous section has been identified, that the probability of backhaul vehicles will change over the course of the week. It is important to identify, whether the same evolution of probability change is in all countries. A sample of 19 countries can be observed, that neighbors of Slovakia had the best offer of backhaul. These states are also observed separately within its area of occurrence in Europe. In particular, they are Eastern European countries, where, besides Slovakia, Poland, Hungary, the Czech Republic, Austria and Slovenia are included. In these countries, there was a return offer of transportation to Slovakia on the average of $53.4 \%$, as can be seen in Figure 2. The biggest transportation offer can be reached in the Czech Republic, other countries in this group reaching average values up to Hungary, where the return transportation offer reaches less than $27 \%$, which is below the average of other states.

\section{Eastern Europe}

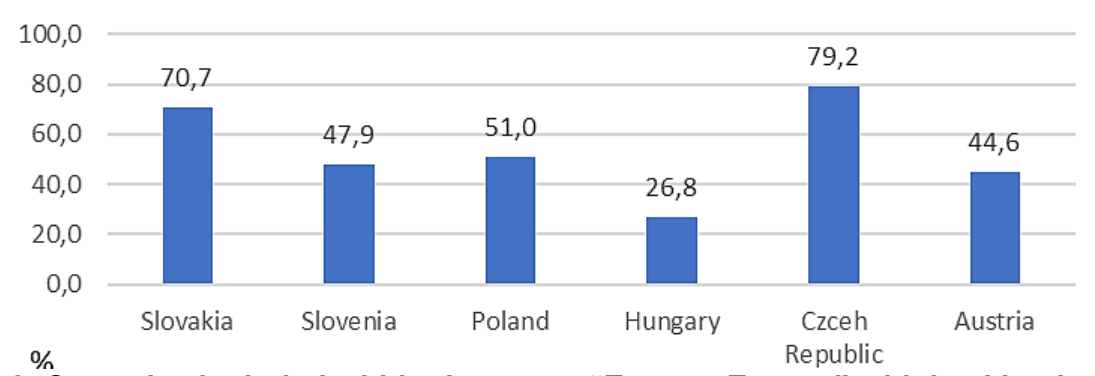

Fig. 2. Countries included within the group "Eastern Europe" with backhaul offer. Source: processed by the authors

Consequently, the observed state sample a group of states with a similar geographic arrangement was created within Europe. In particular, the states of southern Europe, including countries such as Italy, Spain, Bulgaria, Romania, Serbia and Turkey. These countries have an average value of backhaul transportation to Slovakia with a value of $11.4 \%$. Individual bids offer of states can be seen in Figure 3. The highest value from the observed country sample reaching Italy, where the return transportation offer is $37 \%$. Other countries in this group achieve sub-average values.

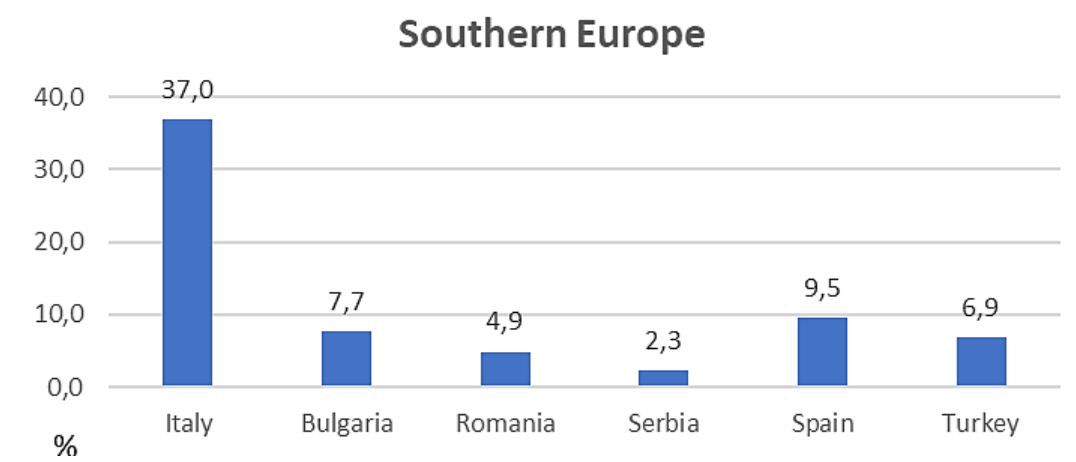

Fig. 3. Countries included within the group "Southern Europe" with return shipping. Source: processed by the authors

Last seen group in the case of backhaul vehicles, there are states included in Western Europe. There are 7 countries in this group. Namely, Belgium, Luxembourg, France, the Netherlands, Germany, Switzerland, United Kingdom. The average value of the transport to Slovakia for these countries it is $13.4 \%$. Figure 4 shows the other offers of states. 


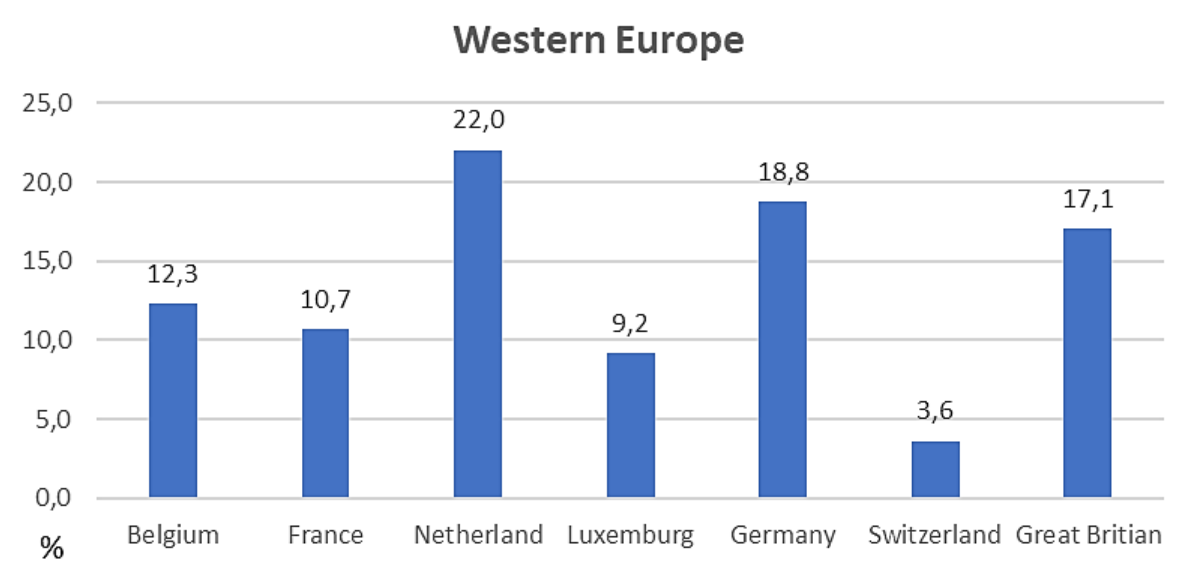

Fig. 4. Countries included within the group "Western Europe" with return shipping.

Source: processed by the authors

States surveyed in the observed sample were selected with intent. The number of 19 countries is a large sample within the territory of Europe. Each country is specific to its location and goods of dispatch, also backhaul on the territory of Slovakia. Figure 5 summarizes the values divided groups. In general, the average value is by backhaul transportation for all countries about value $26 \%$ to the territory of the Slovak Republic.

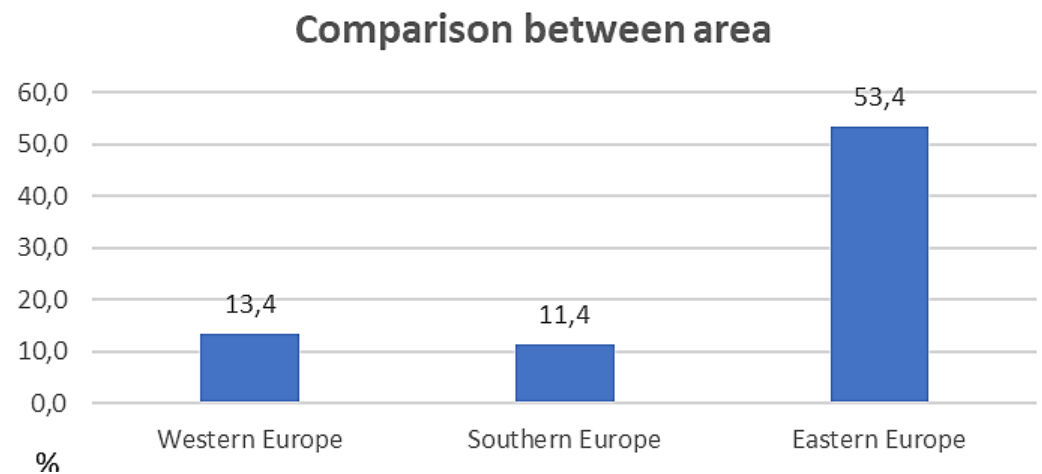

Source: processed by the authors

Fig. 5. Average state values divided into 3 sample groups.

\section{CONCLUSION}

Based on processed research it can be stated that the total cost of the carrier for a specific shipment affect not only cost inputs, but also the destination of the transport operation. In case the carrier is unable to provide backhaul transportation of vehicle, to avoid loss, must increase the shipping cost initial transport. The level of cost increase is dependent from a particular state (Brennan and Buchanan, 1980). Based on research it was concluded that, that countries in specific regions achieve a comparable level of potential backhaul transportation of vehicles. For carriers from Slovakia is the highest level of backhaul use in countries in Eastern Europe. It is also necessary to state that the level of possible backhaul is not constant during the week, but it grows towards the end of the week in all countries.

\section{ACKNOWLEDGEMENTS}

The contribution was elaborated with the support of the Ministry of Education of the Slovak Republic VEGA no. 1/0566/18 Konecny, V.: Výskum vplyvu ponuky a kvality dopravných služieb na konkurencieschopnost' a udržatel'nost' dopytu po verejnej osobnej doprave.

\section{REFERENCES}

Blendon, R. et al., (1997). Bridging the gap between the public and economists views of the economy. Journal of Economic Perspectives, 11(3), pp. 105-118.

Brennan, G., Buchanan, J. (1980). The Power to Tax: Analytical Foundations of a Fiscal Constitution. Cambridge University Press, Cambridge U.K. 
Cyprich, O., Konečný, V., Kilianová, K. (2013). Short-term passenger demand forecasting using univariate time series theory. Promet - Traffic\&Transportation, scientific journal on traffic and transportation research, 25(6), pp. 533-541.

Drozdziel, P., Piasecki, S. (1995). Study of the medthod of assessing the economic efficiency of exploitation cars in a transport company. Folia Societatis Scientarium Lublinensis, pp. 6066.

Edwards, J., Keen, M. (1996). Tax competition and Leviathan. European Economic Review, 40(1), pp.113-134.

Gnap, J., Cajchan, J., Šulgan, M. (2003). Measuring methodology form real bus-stop distances of mass passenger transport. Communications - scientific letters of the University of Žilina, 5(3), pp. 8-9.

Grand, L., Duret, B. (2000). Différentiels de compétitivité et délocalisation des entreprises européennes de transport de marchandises. Transports 400, pp. 99.

Lai, Y.B. (2010). The political economy of capital market integration and tax competition. European Journal of Political Economy, 26(4), pp. 475-487.

Lubanski, N. (2000). Moving Closer together - Trade union europeanisation in the construction sector. Transfer 1, pp. 103-109.

Ondruš, J., Dicová, J. (2010). Creativity in management of transport enterprise. Annals of the University of Petroşani - Economics, 10(4), pp. 75-80.

Osterloh, S., Debus, M. (2012). Partisan politics in corporate taxation. European Journal of Political Economy, 28(2), pp. 215-226.

Poliak, M. (2013). The relationship with reasonable profit and risk in public passenger transport in the Slovakia. Ekonomický časopis/Journal of Economics, 54(7), pp. 668-684.

Poliak, M., Poliaková, A. (2015). Relation of social legislation in road transport on driver's work quality. In: Tools of transport telematics, pp. 300-310.

Poliak, M., Semanová, S., Poliaková, A. (2015). Risk allocation in transport public service contracts. Ekonomski Pregled, 66(4), pp. 384-403.

Rotondo, E. (2013). The legal effect of EU Regulations. Computer Law \& Security Review, 29(4), pp. 437-445. 